\title{
Modelling of Nonpoint Source Pollution in Akagera Transboundary River in Rwanda
}

\author{
U.G. Wali ${ }^{1 *}$, I. Nhapi $^{2}$, A. Ngombwa ${ }^{1}$, N. Banadda ${ }^{3}$, H. Nsengimana ${ }^{4}$, R. J. Kimwaga ${ }^{5}$ and I. Nan- \\ subuga
}

\author{
${ }^{1}$ Faculty of Applied Sciences, National University of Rwanda, P.O. Box 117, Butare, Rwanda \\ ${ }^{2}$ Faculty of Civil Engineering, University of Zimbabwe, BOX MP 167, Harare, Zimbabwe \\ ${ }^{3}$ College of Agricultural and Environmental Sciences, Makerere University, P.O. Box 7062, Kampala, Uganda \\ ${ }^{4}$ Faculty of Sciences, National University of Rwanda, P.O. Box 117, Butare, Rwanda \\ ${ }^{5}$ University of Dar es Salaam, Department of Water Resources Engineering, P. O. Box 35131, Dar es Salaam, Tanzania \\ ${ }^{6}$ Faculty of Engineering, Kyambogo University, P.O.Box 1, Kyambogo, Uganda
}

\begin{abstract}
In this paper, we to assess the level of pollution in the Akagera Transboundary River. The followings parameters namely $\mathrm{NH}_{4}-\mathrm{N}, \mathrm{NO}_{3}-\mathrm{N}, \mathrm{PO}_{4}-\mathrm{P}$, Total Dissolved Solids (TDS), conductivity, $\mathrm{pH}$, Temperature, and Turbidity were identified and quantified. Sampling was conducted a monthly basis from March 2008 to February 2009 at eleven sampling points on the Akagera River system. The landuse and land form characteristics were studied using satellite imagery and ground truthing. From this pollution reduction factors in terms of $\mathrm{kg} / \mathrm{ha}$.yr of pollution load were developed for each landuse type and used for developing the model. Rainfall and river flow data were obtained from gauging stations in and around the river. Water quality parameters particularly values of $\mathrm{NH}_{3}-\mathrm{N}$ changed from 0 to $2.36 \mathrm{mg} / \mathrm{l}, \mathrm{NO}_{3}-\mathrm{N}$ from 1.8 $\mathrm{mg} / \mathrm{l}$ to $314.4 \mathrm{mg} / \mathrm{l}$ and $\mathrm{PO}_{4}-\mathrm{P}$ from $0.02 \mathrm{mg} / \mathrm{l}$ to $19.3 \mathrm{mg} / \mathrm{l}$. Field observations supported with computed export coefficient values showed that bare soils are the most influencing negative factor on water quality in the Akagera River.
\end{abstract}

Keywords: Akagera river, nutrients, water pollution, water quality modelling, lake Victoria.

\section{INTRODUCTION}

Environmental issues such as climatic change, ozone depletion, biodiversity, erosion, and deforestation point source and non-point source pollution (NPS) pollutants are problems of global concern. These problems are exacerbated by the basic trends in world population and consumption. World population has doubled since 1950 and is expected to reach 9.4 billion by the middle of this century. The foremost global issue is satisfying the ever-growing need for natural resources to meet food and living standard demands, while minimizing impacts upon an environment that already shows signs of serious levels of degradation [1]. Barring unexpected technological breakthroughs, sustainable Agriculture is viewed as the most viable means of meeting demands of the projected world's population. The concept of sustainable Agriculture is predicated on a delicate balance of maximizing crop productivity and maintaining economic stability while minimizing the utilization of finite natural resources and the detrimental environmental impacts of associated NPS pollutants.

Without question, Agriculture and poor land-use are currently acknowledged as the biggest contributors of NPS pollutants to water resources. The most common NPS pollutants

*Address correspondence to this author at the Faculty of Applied Sciences, National University of Rwanda, P.O. Box 117, Butare, Rwanda; Tel: +259788877174; E-mail: ugwas@yahoo.com include eroded sediments, fertilizers, pesticides, organic manures, trace elements and sewage sludge. This presents a dilemma because on one hand, there is the growing pressure of meeting the food demands of a constantly growing world population, but in so doing, the likelihood of detrimentally impacting the environment with NPS pollutants seems inevitable. The ability to assess and understand the fate of NPS pollutants in water bodies is a key concern in maintaining the delicate balance between crop productivity and the detrimental environmental impacts of NPS pollutants, which is the cornerstone of sustainable Agriculture. There is strong and ever-growing awareness of NPS pollution, most of this concern has historically been focused on the contamination of surface water resources. The significance of the NPSpollution lies in the ramifications to human health. The acute health effects attributed to the consumption of high dosages of contaminants have been well known, but now chronic health effects from low dosages of NPS pollutants are becoming more apparent as their effects surface (International Joint Commission, 1993). Numerous researchers e.g., [2-10] over the past decades have sought to study NPS pollution. Globally, 30 to $50 \%$ of the earth surface is believed to be affected by NPS pollutants [5]. As noted by researchers, such as [10], Lake Victoria has undergone substantial and very negative changes, especially over the last 30 years. One of the driving factors is nutrient enrichment of the Lake from human activities in the catchment, which is causing eutro- 

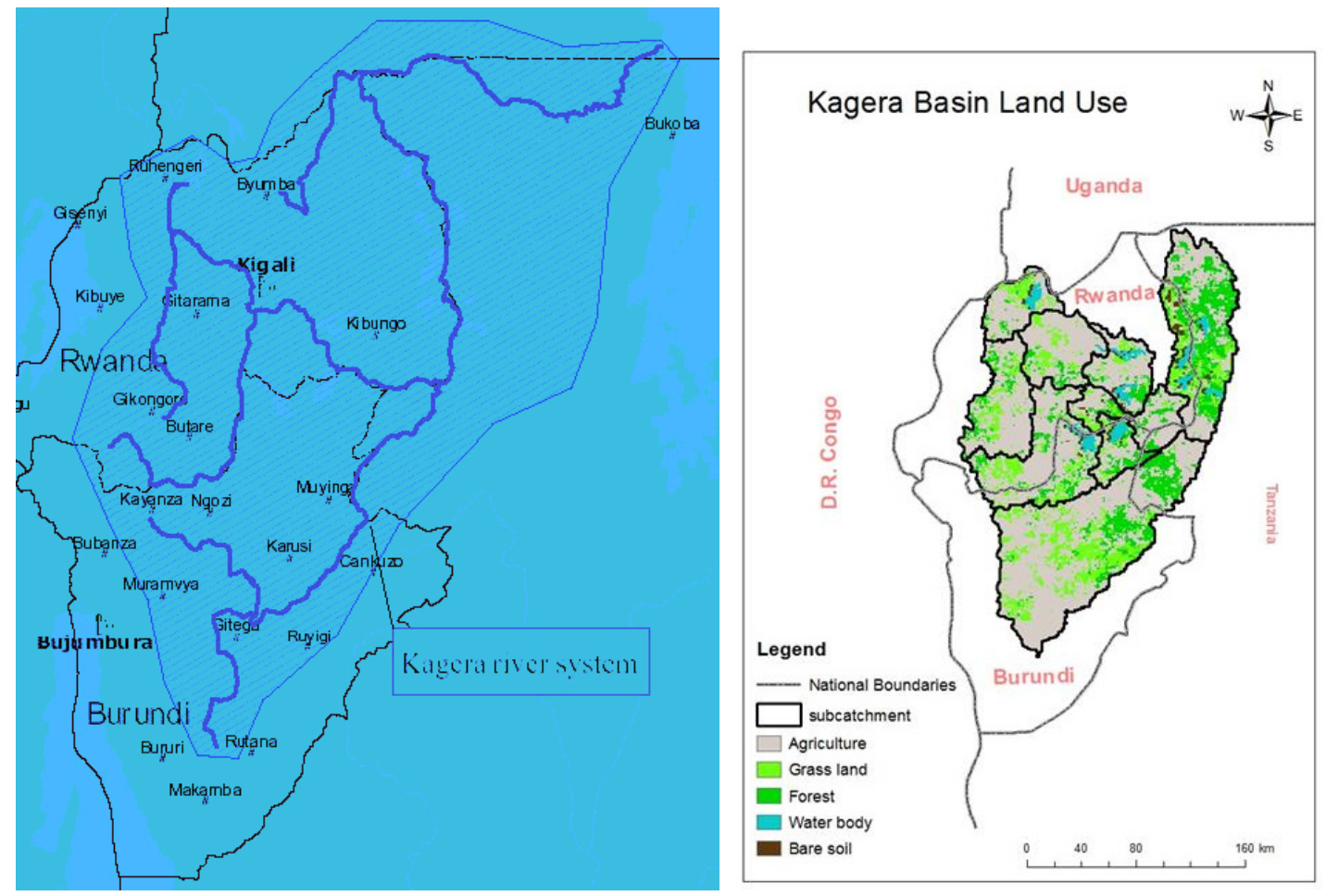

Fig. (1). Akagera River basin (a) location, and (b) land-use.

phication. This has been associated with, among others, the rapid proliferation of water hyacinth, alga blooms, and with general disruption of the lake ecosystem [11]. Nutrients input in Lake Victoria appear to originate mainly from atmospheric deposition and land runoff through its tributary rivers [12].

The complexity of assessing NPS pollution in the Lake Victoria basin necessitates a measurement of this kind of pollution in the context of individual tributary that feed into the lake. The Akagera River is the main tributary of Lake Victoria. The River has a total length of $785 \mathrm{~km}$. Its average flow is estimated at $261 \mathrm{~m}^{3} / \mathrm{s}$ at the point where it enters Lake Victoria and it contributes about $33.5 \%$ of the total inflow of Lake Victoria [9]. In comparison, with other tributaries inflows; contribute approximately $778.3 \mathrm{~m}^{3} / \mathrm{sec}$ corresponding to $66.5 \%$. Despite the importance of the Akagera River to the Lake Victoria basin, there appears to be no comprehensive studies on its contribution and/or NPs pollutants loads and dispersion into Lake Victoria. It is critical that this knowledge gap be filled in order to ably predict the impacts such pollutant on water quality, aquatic life and livelihoods in the lake basin. Therefore, the main objective of this research is to assess the level NPS pollution in the Akagera Transboundary River. In a further step, an export coefficient model is proposed in this research so as to give an insight into the processes related to non-point source pollution on the River in the short and long term periods. Export coefficients represent the quantity of nutrients generated per unit area per unit time $(\mathrm{kg} / \mathrm{ha} / \mathrm{yr})$. Use of export coefficients is based on the assumption that a given land use activity (e.g., agricultural, urban, or forest) will yield a specific quantity of nutrients to a downstream water body $[13,14]$. The used export coefficient to determine the contribution of nonpoint source nutrient to the rivers is an important watershed man- agement tool. The outputs of these type models gives a clear nature and trend for the contribution of each land use activity in a given watershed and are valuable information that policy makers could use in planning strategies for watershed management to improve and control surface water quality.

\section{MATERIALS AND METHODS}

\subsection{Description of the Study Area}

The Akagera River is the largest of the 23 rivers that drain into Lake Victoria and it is the most remote head stream of the Nile River [15]. The River is formed by the confluence of two rivers: Nyabarongo and Akanyaru Rivers. The Akagera River crosses the Eastern part of Rwanda before forming the border between Rwanda and Tanzania. Further downstream, it forms the border between Uganda and Tanzania before flowing into Lake Victoria as shown in Fig. (1). The Akagera River Basin has an area of about 57,364 $\mathrm{km}^{2}$ and is distributed between different countries notably Burundi, Rwanda, Uganda and Tanzania as shown in Table $\mathbf{1}$, and is estimated to have a population of 14 million people [16].

The Akagera River contributes about $33.5 \%$ of the annual inflows into the lake, over twice as much as the next largest river, the Nzoia in Kenya [17]. The River is very important in terms of hydrological regime within Rwanda. The Akagera Basin covers $67 \%$ of the total surface area of Rwanda which is equivalent to $20,977 \mathrm{~km}^{2}$, it has a surface area of about $5 \mathrm{~km}^{2}$, with an average river depth of about $6 \mathrm{~m}$. The land-use of the basin is predominantly agriculture, grassland and forest as shown in Fig. (1b). The altitude in the Akagera Basin varies from $1,200 \mathrm{~m}$ to $1,600 \mathrm{~m}$ above sea mean level in the east and rises above $2,500 \mathrm{~m}$ in the west with peaks reaching $4,500 \mathrm{~m}$ in the north. The area generally has four seasons: a short dry season from January to February; a rainy 
Table 1. Summary of Selected Sampling Stations and Rationale for their Selection

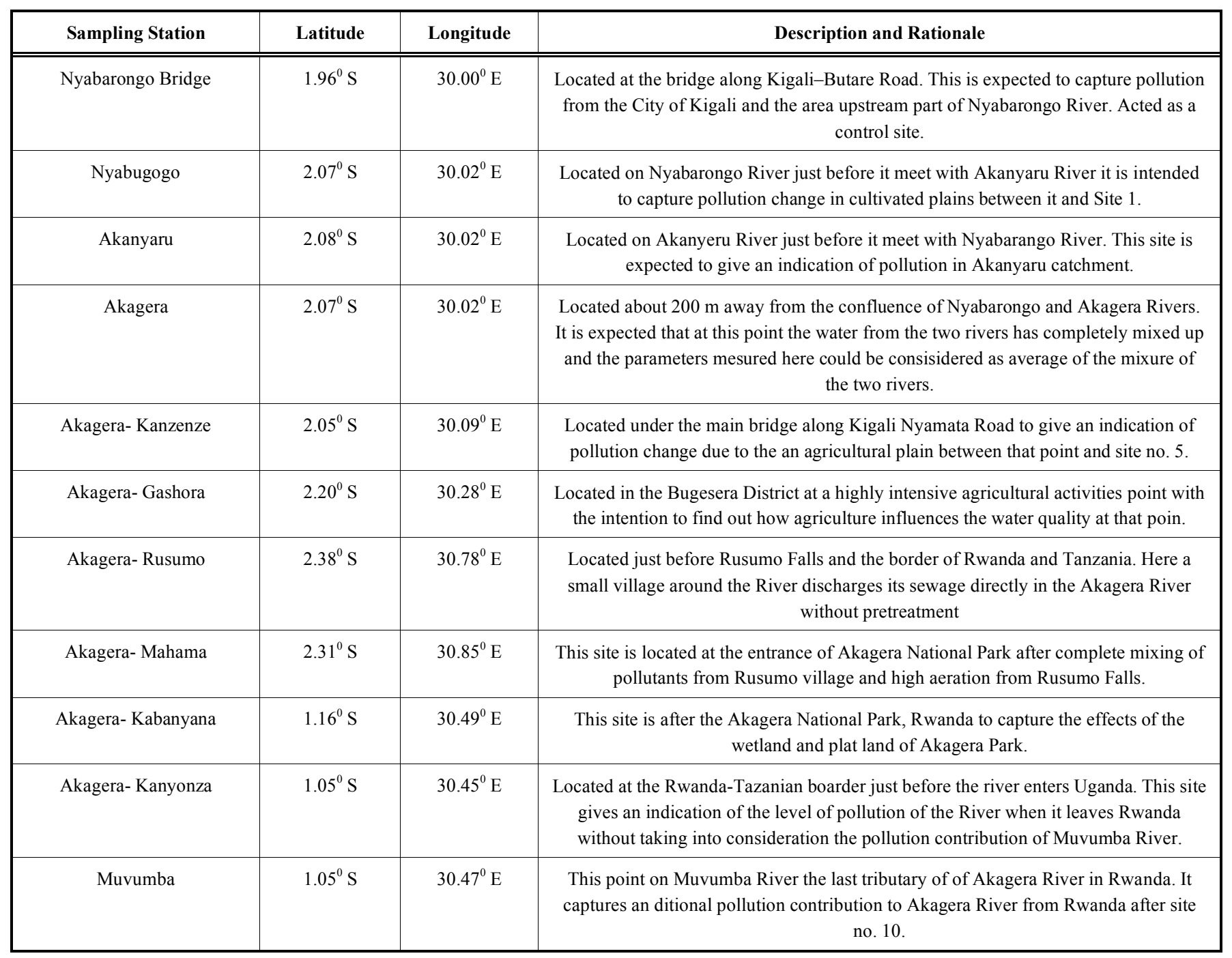

season from March to May; a long dry season from June to September; and another rainy period from October to December. Annual rainfall varies from less than $600 \mathrm{~mm}$ over the eastern part of the basin up to $1,800 \mathrm{~mm}$ and above in the west, where most of the runoff is generated. Steep slopes and heavy rainfall result in erosion and high river sediment loads [18]. However, the river flows are attenuated by a number of lakes, and in particular by floodplains and associated lakes above and below the Rusumo Falls. The peak flow occurs in April in the upper tributaries, in May at Kigali and Rusumo Falls. The terrain is mountainous, declining eastward toward the Tanzanian border [19]. The central part of the basin in Rwanda is covered by rounded hills and large valleys with an altitude between 1,500 and 2,000 m. In the east, the hills give way to a large region with numerous lakes and marshes.

\section{Selection of Sampling Sites}

Eleven water quality monitoring stations Fig. (2) located along the Akagera River as summarized in Table $\mathbf{1}$ were selected. Sites were selected to cater for variation in land-uses and land-use patterns. The downstream stations were carefully selected to encompass additional landuse features such as Akagera National Park, grazing and other small agricul- tural practices. Stations 2 through 6 were characterized by intensive agricultural activities very close to the river whereas stations 1,7 through 10 are surrounded by a big floodplain which may play an important role of riparian buffer and sediment stripping.

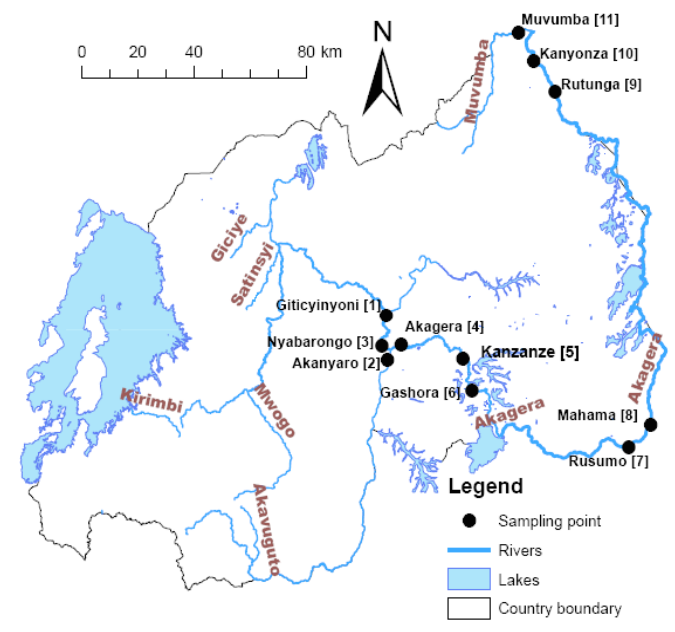

Fig. (2). Location of the sampling points. 
Table 2. ANOVA Summary Guide

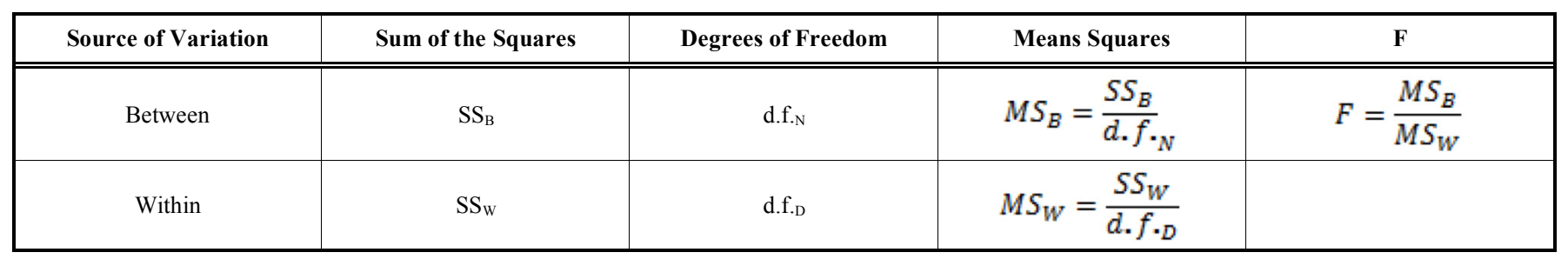

Table 3. Summary of Land Use with Area and Export Coefficient for Diffirent Nutrients

\begin{tabular}{|c|c|c|c|c|}
\hline \multirow[t]{2}{*}{ Initial Land Use } & \multirow[t]{2}{*}{ Grouped Land Use } & \multicolumn{3}{|c|}{$\begin{array}{l}\text { Export Coefficient } \\
\mathbf{k g}, \mathbf{k m}^{-1} \text { per year }\end{array}$} \\
\hline & & Nitrates & Ammonia & Phosphates \\
\hline Dry cropland and pasture & \multirow{2}{*}{ Agriculture } & \multirow{2}{*}{285} & \multirow{2}{*}{5} & \multirow{2}{*}{9} \\
\hline Cropland and woodland mosaic & & & & \\
\hline Shrubland & \multirow[t]{2}{*}{ Grassland } & \multirow[t]{2}{*}{90} & \multirow[t]{2}{*}{1} & \multirow[t]{2}{*}{2} \\
\hline Savanna & & & & \\
\hline Deciduous bread leaf forest & \multirow{2}{*}{ Forest } & \multirow{2}{*}{23.6} & \multirow{2}{*}{2} & \multirow{2}{*}{1.5} \\
\hline Evergreen & & & & \\
\hline
\end{tabular}

\subsection{Sample Collection and Analysis}

The study was conducted during a period of eleven month from February to December 2008. Samples were collected on monthly basis using grab methods and store in 500 $\mathrm{ml}$ plastic bottles that has been rinsed first with $\mathrm{HCl}$ to avoid contamination and pollutants adsorption and then with distilled water [20]. Before storing the sample, the bottles were rinsed three times with the sample water. Samples were taken from the free flowing section of the stream at each station approximately at the middle of a river and at depth of about $20 \mathrm{~cm}$ below the surface. Testes were carried out in the field in the case of temperature, $\mathrm{pH}$, conductivity, turbidity and total dissolved solids. While nitrate, ammonia and phosphates were measured in the laboratory, the samples for their test were transported to the laboratory in a cooler box with ice. All tests were conducted using $\mathrm{HACH}$ Calorimeter in accordance to [21]. Where the test was not carried out immediately on reaching the laboratory the samples are preserved in a freezer at a temperature of about $0^{\circ} \mathrm{C}$ before the analysis.

As mention earlier eleven sampling points was monitored for twelve months the collected data were then arranged in tables of eleven columns (sampling sites) and twelve rows (sampling months). To test the variability of the collected data the one-way-ANOVA (F-test) was found appropriate, as this give opportunity for testing the variability at one sampling point for the whole period and within the different sampling points. The followed procedure is as details in [22] and the approach for presentation of the result statistics are summaries in Table 2.

\subsection{Land-use Data and Analysis}

The land use and catchment boundary digitized data for the study was obtained from GeoSFM for Africa [23]. The catchment boundary of the study area was used to extracted land use from the GeoSFM land use map of Africa. The extracted land use for the study area comprises of nine different land uses which were then regroup into five closely related land uses for convenience Fig. (1b) and Table $\mathbf{3}$ using the classification tools of ArcMap in ArcGIS environment and the export coefficient of each land use class for the export of nitrate, ammonia and phosphate were adopted from [24].

$$
L=\sum_{i=1}^{i=n} C_{i} \frac{A_{i}}{1000}, \ldots 1
$$

where $\mathrm{L}$ is the nutrient load in $\mathrm{kg}$ per annum and $\mathrm{C}$ is the export coefficient for the given land use in $\mathrm{kg}$ per hectare per annum, $\mathrm{A}$ is the in square kilometer and 1000 is the coefficient for conversion of hectares to kilometer square.

\section{RESULTS AND DISCUSSION}

\subsection{Pollution levels along the Akagera River}

Table 4 present the summary results of statistical test one-way-ANOVA conducted for the five measured parameters vis: temperature, $\mathrm{pH}$, nitrates, ammonia and phosphates at the $0.5 \%(\alpha=0.005)$ level of significance. The results statistic indicate that there is significant variation in the measured values of temperature of $\mathrm{pH}$ between the tested samples from different sampling points and within the samples from the same point measured in different months. Though the $\mathrm{pH}$ 
Table 4. ANOVA Summary for Temperature, $\mathrm{pH}$, Nitrates, Ammonia and Phosphates

\begin{tabular}{|c|c|c|c|c|c|c|}
\hline & Statistics & Temperature & pH & Nitrate & Ammonia & Phosphates \\
\hline \multirow{2}{*}{ Sum of squares } & $\mathrm{SS}_{\mathrm{B}}$ & 53.6 & 5.39 & 16959.5 & 2.14 & 47.0 \\
\hline & $\mathrm{SS}_{\mathrm{W}}$ & 114.6 & 8.55 & 457280.4 & 23.16 & 44074.4 \\
\hline \multirow{2}{*}{ Degrees of freedom } & d.f. ${ }_{\mathrm{N}}$ & 10 & 10 & 10 & 10 & 10 \\
\hline & d.f.p & 62 & 58 & 93 & 96 & 93 \\
\hline \multirow{2}{*}{ Mean squares } & $\mathrm{MS}_{\mathrm{B}}$ & 5.36 & 0.539 & 1696 & 0.214 & 4.7 \\
\hline & $\mathrm{MS}_{\mathrm{W}}$ & 2.01 & 0.14 & 4970.4 & 0.244 & 479.1 \\
\hline \multirow{2}{*}{ F-value } & $\mathrm{F}$ & 2.66 & 3.85 & 0.341 & 0.87 & 0.0098 \\
\hline & $\mathrm{F}_{\mathrm{O}}$ & 1.99 & 2.04 & 1.95 & 1.95 & 1.95 \\
\hline
\end{tabular}

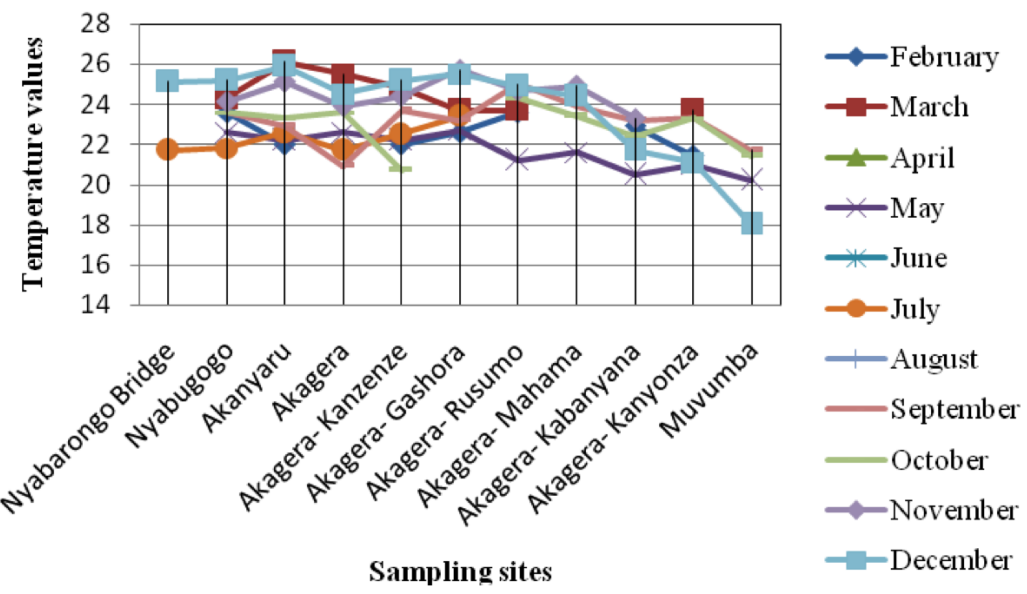

Fig. (3). Temperature values at different sampling points and months.

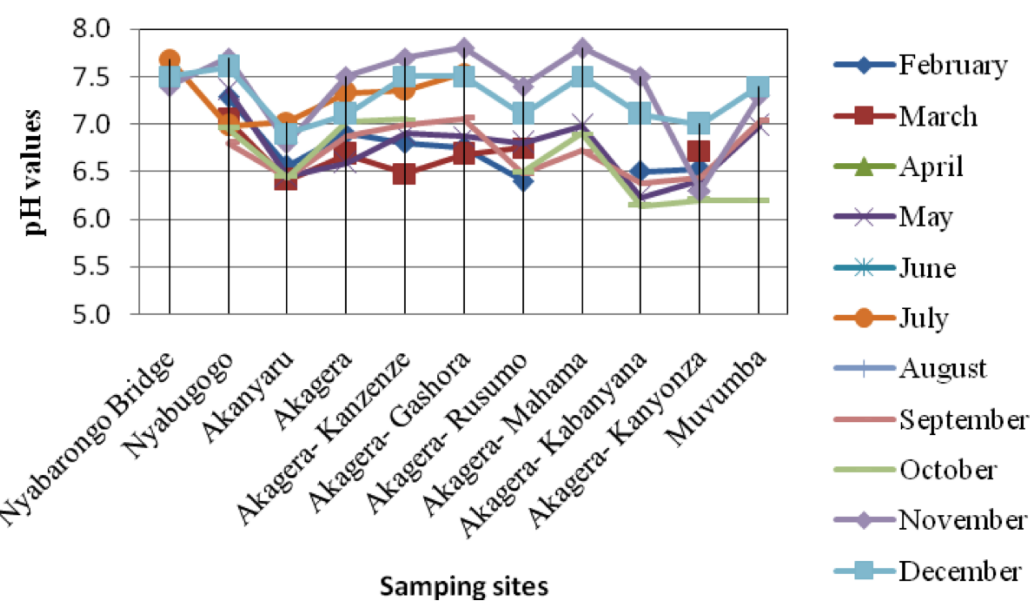

Fig. (4). $\mathrm{pH}$ values at different sampling points and months.

varies as suggested by the statistical test it is important to note that the ranges are still with the fresh water designated uses and criteria [25]. The However, for the nutrients, Nitrate, Ammonia and Phosphates it is suggested that there is no sufficient evidence to conclude that there is a difference in the concentration of the parameters at the same sampling points in different months and at different sampling points.
To give an indication of values and concentration of parameters at each sampling point and in different months Fig. (3) Fig. (7) are presented. The concentration of Nitrates and Phosphates for all the sites and for all the period of the study exceeded the USGS background nutrient water quality in stream and shallow ground water which are 0.6 and 0.02 $\mathrm{mg} / \mathrm{L}$ respectably [26]. 


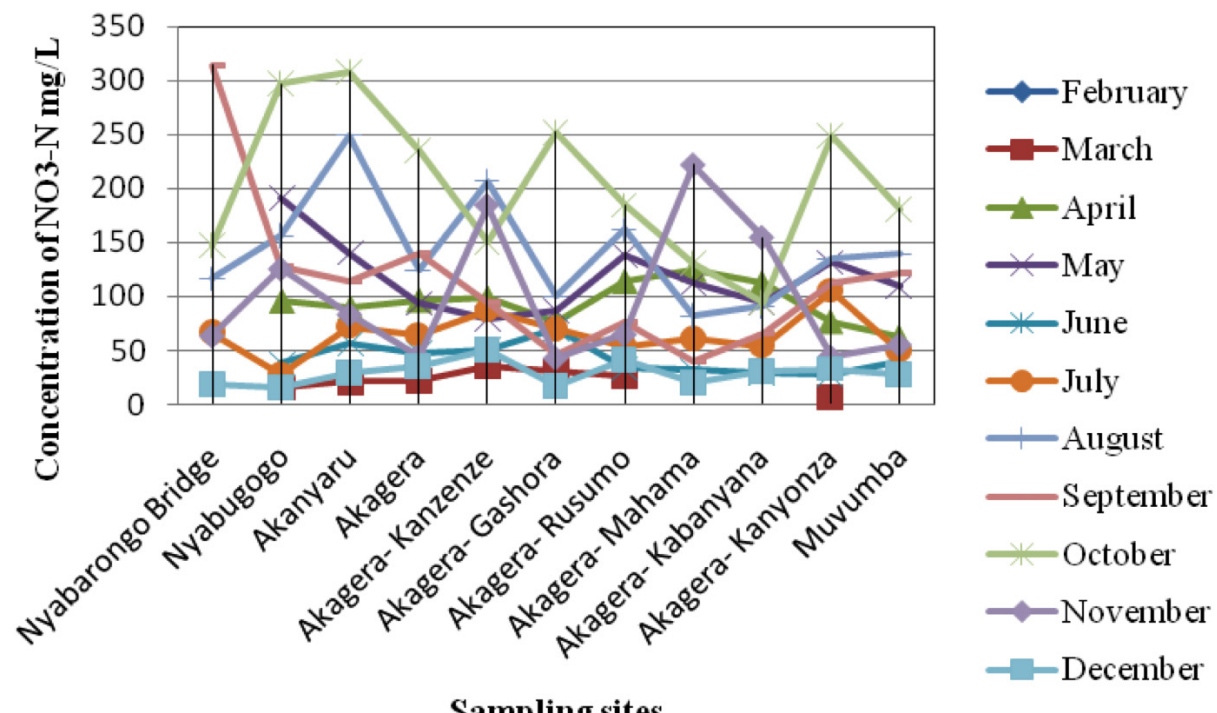

Fig. (5). Concentration of Nitrates at different sampling points and months.

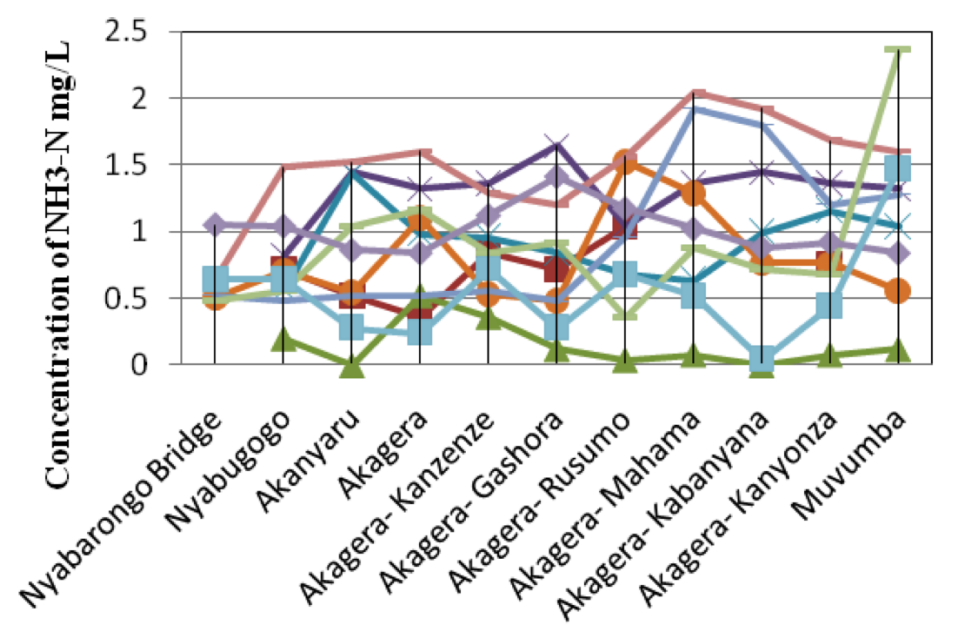

Sampling sites

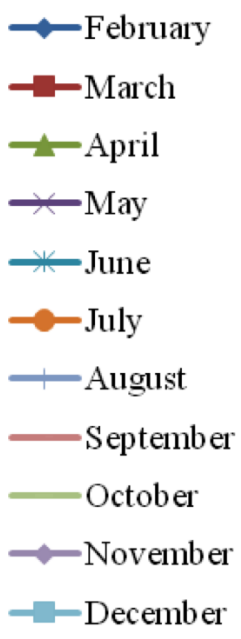

Fig. (6). Concentration of Ammonia at different sampling points and months.

Excessive nutrients (nitrogen and phosphorus) can cause negative ecological impacts to waterbodies by stimulating harmful algal blooms. Algal blooms block sunlight and result in the destruction of submerged aquatic vegetation (SAV). SAV serves as critically important habitat and food for many organisms. Algal blooms eventually die off and consume dissolved oxygen (DO) from the water column. Low DO concentrations lead to die off of aquatic organisms. One result of algal blooms is decreased biological diversity and populations, including smaller populations of game and commercial fish. Excessive nutrients also pose public health risks. Algal blooms can cause taste and odor problems in drinking water. Hazardous algal blooms can cause respiratory distress and neurological problems in swimmers. Excessive nitrates can cause blue baby syndrome [27]. It is therefore recommended that watershed management strategy be developed and implemented for the improvement and control of water quality in the Akagera catchment.

\subsection{Pollutants Export}

The annual nutrient export into the surface water in the study area for Nitrate, Ammonia and Phosphate are presented in Table $\mathbf{5}$ in kilogram per square kilometre per year and in percentage for the catchment. Runoff from land cultivation, forestry operations and pasture preparations is often associated with increased phosphate exports, with phosphorus adsorption to soil supplying phosphorus through erosion processes.

The relatively high nitrates and ammonia $\left(\mathrm{NO}_{3}-\mathrm{N}\right.$ and $\mathrm{NH}_{3}-\mathrm{N}$ ) catchment exports may be associated with catchment based nitrification processes. As nitrogen enters the soils bacteria convert it to gaseous nitrogen that rises out of the soil and into the atmosphere (i.e. reducing TN exports). Another factor that is just as important as nutrient loads is the composition, and reactivity (digestibility), of the organic matter source, that can contain a substantial proportion of the nitrogen and phosphorus exported to the receiving waters. 


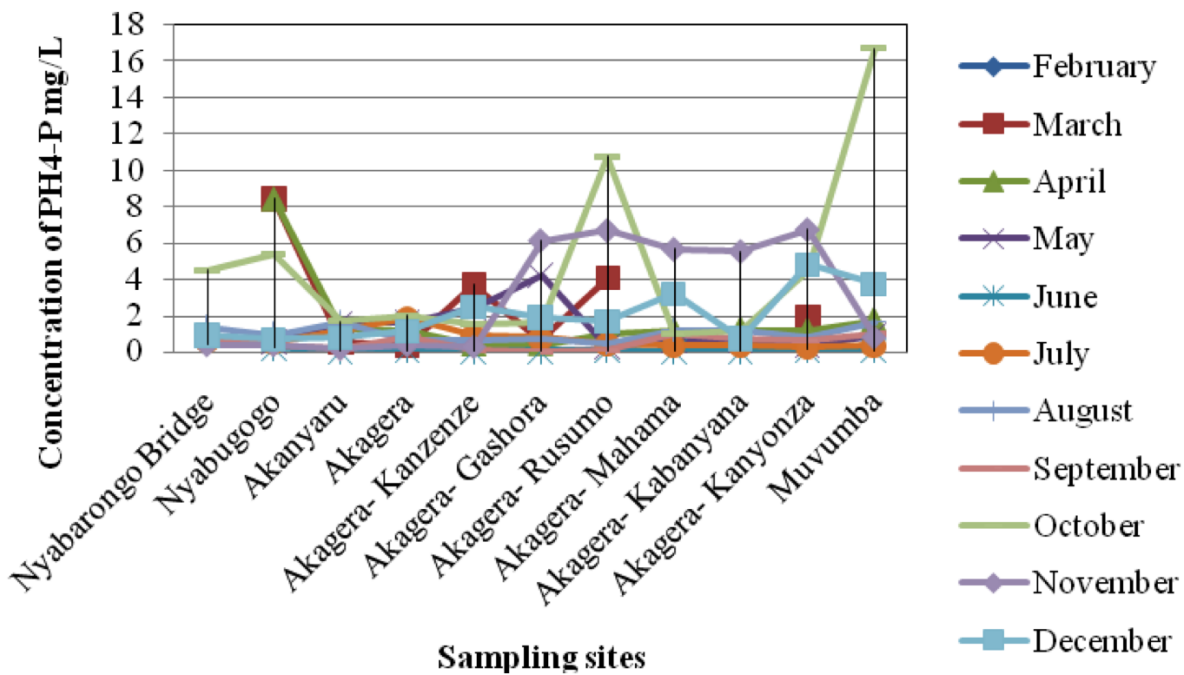

Fig. (7). Concentration of Phosphates at different sampling points and months.

Table 5. Nutrients export for Nitrates, Ammonia and Phosphates in $\mathrm{kg} / \mathrm{km}^{2} /$ Year and in Percentage for the Catchment

\begin{tabular}{|c|c|c|c|c|c|c|c|c|}
\hline \multirow{2}{*}{ Land Use } & \multicolumn{2}{|c|}{ Area } & \multicolumn{2}{|c|}{ Nitrates } & \multicolumn{2}{|c|}{ Ammonia } & \multicolumn{2}{|c|}{ Phosphates } \\
\hline & Square km & $\%$ & kg sq_km $\mathrm{km}^{-1} /$ year & $\%$ & kg sq_ $\mathrm{km}^{-1} /$ year & $\%$ & kg sq_km ${ }^{-1} /$ year & $\%$ \\
\hline Agriculture & 22823.2 & 63.1 & 6504615 & 89.9 & 114116 & 85.5 & 205409 & 90.2 \\
\hline Grassland & 5872.5 & 16.2 & 528524 & 7.3 & 5872 & 4.4 & 11745 & 5.2 \\
\hline Forest & 6005.8 & 16.6 & 141738 & 2.0 & 12012 & 9.0 & 9009 & 4.0 \\
\hline Barren land & 480.7 & 1.3 & 6729 & 0.1 & 481 & 0.4 & 481 & 0.2 \\
\hline Water bodies & 1011.1 & 2.8 & 54599 & 0.8 & 1011 & 0.8 & 1011 & 0.4 \\
\hline Total & 36193.3 & 100 & 7236206 & 100 & 133492 & 100 & 227654 & 100 \\
\hline
\end{tabular}

When land use is changed from native vegetation to grassland, the organic matter entering the streams is very different. Grassy organic matter is much more digestible and requires more oxygen as part of the digestion process. This can lead to dissolved oxygen depletion in receiving waters which can lead to major water quality problems which is the high risk threatening the Akagera River. It could be suggested that the influence of land use on River integrity is scale dependent. In-stream habitat structure and organic matter inputs are determined primarily by local conditions such as vegetative cover at a site, whereas nutrient supply and sediment delivery are influenced by regional conditions, including landscape features and land use at some distance upstream and lateral to stream sites.

\section{CONCLUSIONS}

The result of this study shows that the Akagera River is very highly polluted with nutrient viz: nitrate, ammonia and phosphate beyond the recommended level for aquatic life development in fresh water. The nutrient concentration along the River does not vary for all the sampling sites and for the whole study period. The value of temperature and $\mathrm{pH}$ both with site and sampling period, but all are within the recommended value the fresh water designated uses and criteria. As could be expected agriculture is the main source of nonpoint source pollution in the catchment with about $89.9 \%$,
$85.5 \%$ and $90.2 \%$ for nitrates, ammonia and phosphates respectably.

Based on the findings of this study, the following recommend are suggested: (1) Prepare and execute watershed management strategies for water quality remediation and control. This could be implemented in are regional coordinated efforts. (2) Ensure that municipal wastewater are treatment to the accepted standard level it before disposal into the Akagera River. (3) Further research shall be focus on determination nutrient load and their ascertaining their fate in the Akagera River.

\section{ACKNOWLEDGEMENTS}

Acknowledgement is made to (i) SIDA/SAREC through the Inter University Council for Eastern Africa that cofunded this work under the Lake Victoria Research (VICRES) programme and (ii) Nuffic through the WREM Project, a collaborative capacity building project between the National University of Rwanda and the UNESCO-IHE Institute for Water Education.

\section{NOMENCLATURE}

$\begin{array}{lll}{ }^{\%} & = & \text { Percentage } \\ { }^{0} \mathrm{C} & = & \text { Degree Centigrade }\end{array}$




\begin{tabular}{|c|c|c|}
\hline$A_{i}$ & $=$ & Area, $\mathrm{km}^{2}$ \\
\hline $\mathrm{C}_{\mathrm{i}}$ & $=$ & $\begin{array}{l}\text { Export coefficient of the } \mathrm{i}^{\text {th }} \text { land use } \\
\mathrm{kg} / \mathrm{h} / \mathrm{year}\end{array}$ \\
\hline d.f. $D$ & $=$ & $\begin{array}{l}\text { Degree of freedom for number o } \\
\text { groups }\end{array}$ \\
\hline d.f. $\cdot_{N}$ & $=$ & Degree of freedom for the total samples \\
\hline F- value & $=$ & Calculated F-test value \\
\hline $\mathrm{F}_{\mathrm{O}}$ & $=$ & $\begin{array}{l}\text { Critical F-test value, determine from } \\
\text { the table }\end{array}$ \\
\hline ha & $=$ & Hectares \\
\hline $\mathrm{kg}$ & $=$ & Kilogram \\
\hline $\mathrm{kg} / \mathrm{ha} / \mathrm{yr}$ & $=$ & Kilogram per hectare per year \\
\hline $\mathrm{km}^{2}$ & $=$ & Square kilometres \\
\hline $\mathrm{L}$ & $=$ & Pollutant load, $\mathrm{kg} / \mathrm{km}^{2} /$ year \\
\hline $\mathrm{m}^{3} / \mathrm{s}$ & $=$ & Cubic meters per second \\
\hline $\mathrm{mg} / 1$ & $=$ & Milligram per litre \\
\hline $\mathrm{MS}_{\mathrm{B}}$ & $=$ & Mean squares between groups \\
\hline $\mathrm{MS}_{\mathrm{w}}$ & $=$ & Mean squares within groups \\
\hline $\mathrm{NH}_{4}-\mathrm{N}$ & $=$ & Ammonia -nitrogen \\
\hline $\mathrm{NO}_{3}-\mathrm{N}$ & $=$ & Nitrate -nitrogen \\
\hline $\mathrm{PO}_{4}-\mathrm{P}$ & $=$ & Phosphate \\
\hline $\mathrm{SS}_{\mathrm{B}}$ & $=$ & Sum of the squares between groups \\
\hline $\mathrm{SS}_{\mathrm{W}}$ & $=$ & Sum of the squares within groups \\
\hline
\end{tabular}

Greek

$\alpha$

\section{Subscripts}

$\begin{array}{lll}\mathrm{B} & = & \text { Between } \\ \mathrm{D} & = & \text { Number of groups } \\ \mathrm{i}-\mathrm{n} & = & \text { Range of variables } \\ \mathrm{N} & = & \text { Number of total samples } \\ 0 & & \text { Angle in Degrees } \\ \mathrm{W} & & \text { Within }\end{array}$

\section{Acronyms}

$\begin{array}{lll}\mathrm{ANOVA} & = & \text { Analysis of variance } \\ \mathrm{DO} & = & \text { Dissolved oxygen } \\ \mathrm{E} & = & \text { East of Greenwich meridian } \\ \mathrm{HACH} & = & \text { South of the equator } \\ \mathrm{S} & = & \text { Non-point source pollution } \\ \mathrm{NPS} & = & \text { Netherlands Universities Foundation } \\ \mathrm{NUFFIC} & \text { for International Cooperation }\end{array}$

the Swedish International Development Cooperation Agency

\begin{tabular}{|c|c|c|}
\hline TDS & $=$ & Total Dissolved Solids \\
\hline USGS & $=$ & United State Geological Survey \\
\hline \multicolumn{2}{|c|}{ UNESCO-IHE= } & $\begin{array}{l}\text { United Nations Educational, Scientific } \\
\text { and Cultural Organization - Institute of } \\
\text { Water Education }\end{array}$ \\
\hline VICRES & $=$ & Lake Victoria Research Initiative \\
\hline WREM & $=$ & $\begin{array}{l}\text { Water Resources and Environmental } \\
\text { Management }\end{array}$ \\
\hline
\end{tabular}

\section{REFERENCES}

[1] D. L. Corwin, and R.J. Wagenet, "Application of GIS to the modelling of modelling of non-point source pollutants in the vadose zone: A conference overview", Journal of Environmental Quality, Vol. 25, No. 3, pp. 403-11, 1996.

[2] R. S. Clemente, S. O. Prasher, S. F. Barrington, and W.D. Marshall, "Impact of Agricultural Chemical on Water Resources" in Proceedings of the sixth IWRA World Congress on Water Resources, 1988, pp. 278-89, Ottawa, Canada.

[3] J. L. Gray, "Providing access, assuring availability: Groundwater protection and water access issues" in Proceedings of the sixth IWRA World Congress on Water Resources, 1988, pp. 400-08, Ottawa, Canada.

[4] P. H. Gleick, Water in Crisis: A guide to the World's Fresh Water Resources, England, Oxford University Press, 1993, pp. 449.

[5] D. Pimental, "World Soil Erosion and Conservation", England Cambridge Uni. Press, Cambridge, 1993.

[6] B. Gomez, "Assessing the impact of the 1985 farm bill on sediment related nonpoint source pollution", Journal of Soil and Water Conservation, vol. 50, No. 4, pp. 374-77, 1995.

[7] D.E. Line, D.L. Osmond, R. Gannon, J.A. Gale, J.A. Arnold, S. W Coffey, J. Spooner, and G.D. Jennings. "Nonpoint sources", Water Environment Research, vol. 67, No. 4, pp. 685-700, 1995.

[8] D.W. Kolpin, "Agricultural chemical in groundwater of the Midwestern United States: Relations to land use", Journal of Environmental Quality, vol. 26, pp. 1025-37, 1997.

[9] L.M. Campbell, J.S. Balirwa, D.G. Dixon, and R.E. Hecky. "Biomagnification of mercury in fish from Thruston Bay, Napoleon Gulf, Lake Victoria, East Africa", African Journal of Acquatic Science, vol. 29, No. 1, pp. 91-96, 2004.

[10] E.N. Banadda, F. Kansiime, M. Kigobe, M. Kizza, and I. Nhapi. "Landuse-based non-point source pollution: a threat to Murchison bay water quality in Uganda", Water Quality II Supplement 1: pp. 93-104, 2009.

[11] F. Mwanuzi, H. Aalderink, and L. Mdamo, "Simulation of pollution buffering capacity of wetlands fringing the Lake Victoria", 2002.

[12] P.A.G.M. Scheren, H.A. Zanting, and A.M.C. Lemmens, "Estimation of water pollution sources in Lake Victoria, East Africa: Application and elaboration of the rapid assessment methodology", 2004.

[13] A.M.S. McFarland, and L.M. Hauek, "Determining nutrient export coefficients and source loading uncertainty using in-stream monitoring data". Journal of the American Water Resources Association, vol. 37, 223-36, 2001.

[14] W. Rast, and F. Lee, "Nutrient Loading Estimates for Lakes", Journal of Environmental Engineering, vol. 109, No. 2, pp. 502-18, 1983.

[15] B. Bosnjakovic, "UN/ECE Strategies for Protecting the Environment with Respect to International Watercourses", The Helsinki and Espoo Conventions, pp. 47,50, 2001.

[16] M.M. Andjelic, Cited in Strategy for Support Sustainable Development in the Lake Victoria Region, SIDA, Stockholm, Sweden, 1999.

[17] J.V. Sutcliffe and Y.P. Parks, "The Hydrology of the Nile” International Association of Hydrological Sciences, IAHS Special Publication No. 5, Wallingford, England, pp. 179, 1999.

[18] E. Mpyisi, "Food security survey: phase 1: Agricultural production and land use season 2000A", Kigali: Rwanda Ministry of Agriculture, Animal Resources, and Forestry. p. 19, 2000. Available at 
http://www.aec.msu.edu/agecon/fs2/rwanda/ag_prod_2000e.pdf, [accessed February 2, 2011].

[19] FAO, Land and Water Development Division. Review of Water Resource Statistics by Country, 2005. http://www.fao.org/ag/agl/ aglw/aquastat/water_res/rwanda/index.stm

[20] AWWA/WEF/APHA, Standard Methods for the Examination of Water and Wastewater, $21^{\text {th }}$ ed, American Public Health Association, Washington, 2005.

[21] Hach Company, DR/890 Colorimeter Procedures Manual, 2005, p. 616.

[22] A.G. Bluman. Elementary Statistics: A Step By Step Approach. $5^{\text {th }}$ ed. McGraw Hill, Higher Education, Boston 2004, p. 810, 2004.
[23] D. Entenman, Geospatial Stream Flow Model (GeoSFM) Data Sources for Africa. FEWSNET GIS Intern, USGS - National Center for EROS, Sioux Falls, SD, May, 2005.

[24] L. Rui-Min, H. Meng-Chang, and W. Xiu-Juan. Application of the Export Coefficient Model in Estimating Nutrients Pollution of Dahuofang Reservoir Drainage Basin, daliao River, China, 2005.

[25] WAC 173-201A-200, Fresh water designated uses and criteria. Available at http://apps.leg.wa.gov/wac/default.aspx?cite=173201A-200\#, [accessed February 3, 2011].

[26] A. S. Leib, and F. X. Browne, Water Quality Standard for the Great Swamp Watershed, p. 21, 2002.

[27] EPA, US Nation Nutrient Strategy, 2002, p. 21 May, 2007.

Received: December 06, 2010

(C) Wali et al.; Licensee Bentham Open.

This is an open access article licensed under the terms of the Creative Commons Attribution Non-Commercial License (http://creativecommons.org/licenses/by-nc/3.0/) which permits unrestricted, non-commercial use, distribution and reproduction in any medium, provided the work is properly cited. 